\title{
The Effect of Health Promotion on Family Knowledge and Attitude in Preventing the COVID-19 Pandemic
}

\section{Anni Sinaga*}

Lecturer, Diploma of Nursing, Immanuel School of Health Sciences Bandung

\section{ORCID}

Anni Sinaga: https://orcid.org/0000-0002-3992-2681

Corresponding Author: Anni

Sinaga; email:

annisinaga1@gmail.com

Published: 7 February 2022

Publishing services provided by

Knowledge E

(c) Anni Sinaga. This article is distributed under the terms of the Creative Commons

Attribution License, which permits unrestricted use and redistribution provided that the original author and source are credited.

Selection and Peer-review under the responsibility of the IVCN Conference Committee.
G OPEN ACCESS
Abstract. COVID-19 has different genetic characteristics from other corona viruses such as SARSr-CoV and MERSr-CoV. There are still many positive cases of COVID-19 every day. There are nine people who monitor cases of COVID-19 in Baleendah Village. The Baleendah location is surrounded by areas that are already badly affected by COVID-19. This pandemic necessitates health promotion through the family to prevent the transmission of COVID-19. This study aimed to identify the impact of providing health promotion to families on knowledge and attitudes in preventing COVID-19 in the Rancamanyar cluster. This was a pre-experimental study with a one group pre-test and post-test design, using a sample of 74 respondents. The method of collecting data was through a questionnaire that was shared via Google Drive through an online system. Health promotion significantly influenced family knowledge and attitudes in preventing COVID-19. Based on the findings, it is recommended that public knowledge be increased so that the public is aware of how to prevent the transmission of COVID-19 to other people and to other family members.

Keywords: COVID-19 prevention, health promotion, family knowledge and attitudes

\section{Introduction}

Corona Virus Deasease (Covid-19) has been declared by the World Health Organization (WHO) as a global pandemic or disease outbreak that occurred on a wide geographical basis recorded until April 17, 2020, 167 countries exposed to Covid-19 with the number of positive cases of covid-19 as many as 2,074,529 people and the number of deathsreached 139,378 people [1]. National data as of April 22, 2020 recorded 7,418 confirmed positive and 635 deaths. Exposure to Covid-19 infection in Indonesia has spread almost all major cities with the number of positive cases as many as 2,273 people and caused the death of 198 people. People in monitoring are required to self-isolate at home and take specimens (day 1 and day 2). For this reason, health promotion is needed, through the delivery of health messages or transforming health behaviors to the target or society to know the knowledge and attitudes of the community, [2]. Based on studies that have 
been conducted on 6 people who confirmed positive for Covid-19 after traveling from Wuhan, China between December 29, 2019 and January 4, 2020 have symptoms in the form of fever, dry cough (common), weak and severe to cause acute pneumonia [3]. With good knowledge and attitude, it can provide effective prevention to reduce the incidence rate and improve the degree of public health. This knowledge itself has a significant role in shaping one's actions. So that the better the knowledge possessed by everyone, thebetter the disease will be able to do theaction of disease. [4]. One of the characteristics of Covid-19 disease is easily transmitted, so it can quickly infect many people. West Java itself has 762 people who were confirmed positive and 71 people who died on April 22, 2020. Rancamanayar Cluster is in Bandung Regency and surrounded by several sub-districts that are already in the red zone, which makes the community worried about the spread of the covid 19 virus to the rancamanyar cluster. It is very important to know the knowledge and attitudes of families for the prevention of the covid 19 outbreak in China, it was found that the promotion of mental health is very important during the infectious disease outbreak to assist in moderating the perceived threat, social and household economic impact [5], Until now, the knowledge and attitudes of the general public living in the Rancamanayar Cluster regarding COVID-19 are limited.So that researchers feel it is important to assess health knowledge and beliefs related to COVID-19 from the general public during a very critical disease outbreak in order to provide better insight to handle knowledge and attitude gaps related to disease, so that assist in the control and management of flows an ongoing epidemic.therefore researchers are interested to find out "Is there an influence of health promotion on family knowledge and attitudes in the prevention of the covid 19 pandemic in the rancamanyar Bandung Cluster ".

\section{Methods and Instrument}

\subsection{Methods}

The research design used in this study is experimental research. Experimental research(pre experimental research) is a study by conducting an experimental activity (preexperiment) that aims to find out the symptoms or influences that arise as a result of certain treatments or experimentsmen. Based on the problems and goals to be achieved, the type of experimental research used in this study is to use pre-experiments with the design / approach of One Group Pretest Posttest before family intervention and after intervention. 


\subsection{Instrument}

Instruments of knowledge and attitude in this study are instruments that are not standard, by making their own instruments, so it is necessary to test validity and reliability tests first before research using google drive by answering the instruments online. The knowledge instrument has 16 questions about what covid 19 is, signs and symptoms, incubation period, prevention, the application of social distancing, while the attitude instrument contains 41 statements containing family attitudes in preventing covid 19.Validity tests and reliability tests have been conducted in Rancamanyar regency 1 with the number of respondents as20-30 respondents, declared valid with a correlation value greater than 0.361 .

\section{Results}

Based on tabel 3.1 can be seen the results of pre-intervention from 74 respondents. Based on the level of family knowledge on the pre-intervention test,the majority of respondents in the good category yes it was66 respondents (89\%), and the results of pre-intervention family attitudes, the majority of respondents in the category were very good asmany as49 respondents (66\%). Based on the level of family knowledge in the post-intervention test, the majority of respondents in the good category were 72 respondents (97\%), and the results of post-intervention family attitudes, the majority of respondents in the category were very good asmany as60 respondents (81\%).

\section{Part I}

\section{a: wilcoxon test b: paired t test}

Based on the results of calculations using the Wilcoxon comparison test, it can be seen in table 3.3 that there is a significant difference in the level of knowledge between before and after being given health promotion. The p-value (asymp.sig) of 0.014 means that there is a significant difference between pre and post ( $<<0.05 \mathrm{Cl}$ (95\%). In other words, health promotion has a good influence in increasing family knowledge regarding the Covid-19 pandemic.The result of the recapitulation of the paired t-test shows a $\mathrm{p}$ value of 0.001 . If this value is compared with 0.05 , then the $p$-value is smaller than 0.05 . This means that there is a significant difference in family attitudes between before and after being given health promotion. It can be seen from table 3.3 where the average 
TABLE 1: Overview of Knowledge Levels and Attitudes of Pre-Post Intervention Families

\begin{tabular}{|c|c|c|}
\hline Variabel & Jumlah $(n=74)$ & Persentase \\
\hline \multicolumn{3}{|l|}{ of Pretest Knowledge } \\
\hline Good & 66 & $89 \%$ \\
\hline Fair & 8 & $11 \%$ \\
\hline Less & 0 & $0 \%$ \\
\hline Mean \pm SD Pre Knowledge (\% & $85.81 \pm 6.73$ & \\
\hline \multicolumn{3}{|l|}{ Postest knowledge } \\
\hline Good & 72 & $97 \%$ \\
\hline Fair & 2 & $3 \%$ \\
\hline Less & 0 & $0 \%$ \\
\hline Mean \pm SD Pengetahuan Post (\%) & $92.15 \pm 5.86$ & \\
\hline \multicolumn{3}{|l|}{ Pretest Attitude } \\
\hline Very Good & 0 & $0 \%$ \\
\hline Good & 72 & $97 \%$ \\
\hline Fairly Good & 2 & $3 \%$ \\
\hline Not Good & 0 & $0 \%$ \\
\hline Very Bad & 0 & $0 \%$ \\
\hline Mean \pm SD Attitude Pre (1-5) & $3.32 \pm 0.29$ & \\
\hline \multicolumn{3}{|l|}{ Postest Attitude } \\
\hline Very Good & 0 & $0 \%$ \\
\hline Good & 52 & $70 \%$ \\
\hline Fairly Good & 22 & $30 \%$ \\
\hline Not Good & 0 & $0 \%$ \\
\hline Very Bad & 0 & $0 \%$ \\
\hline Mean \pm SD Post Attitude (1-5) & $3.50 \pm 0.27$ & \\
\hline
\end{tabular}

TABLE 2: Bivariate Analysis

\begin{tabular}{l|l|l|l|l|}
\hline Variabel & Pre & Post & p-value & Conclusion \\
\hline Knowledge (\%) & $85.81 \pm 0.29$ & $92.15 \pm 5.86$ & $0.014 \mathrm{a}$ & Signifikan \\
\hline attitude & $3.32 \pm 0.29$ & $3.50 \pm 0.27$ & $0.001 \mathrm{~b}$ & Signifikan \\
\hline
\end{tabular}

value after being given an intervention in both knowledge and attitude is greater than before being given health promotion. Thus, it can be concluded that health promotion has a significant effect on family attitudes towards being better than before.

\section{Discussion}




\subsection{Family knowledge before and after intervention}

Based on the results of the study there was an increase in family knowledge after being given the intervention of 72 respondents $(97 \%)$ of the good category. Many factors influence in efforts to improve a person's health. These factors can be a basis in determining strategies in providing health education. In this study showed the characteristics of respondents influence the acceptance of education delivered. This can encourage respondents to cognitively easily capture what is conveyed from the educator who then receives and performs the ways provided to improve health and prevent a disease that impactshealth. Cognitive perception and acceptance of education about Corona virus disease (COVID-19) in respondents can also be motivated by a history of diseases that are being suffered such as comorbid diseases or chronic diseases are very susceptible to Covid-19 infection because the ongoing disease process can reduce the patient'simmunity. Covid-19 infection can cause impaired physiological function in patients with Jantung disorder [6]. This is a driver for comorbid sufferers to comply with health protocols delivered to prevent the spread of Covid-19. Because coronavirus is a newly discovered infectious disease, it also encourages respondents to hear well about the new information they receive [7]. The level of knowledge of families in rancamanyar cluster is well influenced by several factors, including the age of the majority aged 31-40 years as many as 33 respondents (45\%) because older the age then the level of maturity and strength of a person will be more mature in thinking. They will also spend more time reading. Intellectual ability, problem-solving and verbal ability are reported to be almost noun an at this age [8]. The second level of education, the majorityof undergraduate educationas many as 30 respondents (41\%), because the higher the level of education a person, the better his knowledge and education can also make a person encouraged to always want to look for all the information that will be received so that it becomes new knowledge. More high level of education pearson will be easier to receive information so that the more experience a person has,in this case especially knowledge about efforts to prevent covid-19. [9]

\subsection{Family attitudes before and after intervention}

Based on the results of family attitude research after being given intervention increased to 60 respondents (81\%). The good attitude of the family is the importance of using masks when leaving the house during a pandemic, not going out of the house if there is no urgent need, having to keep a distance of at least 1.5 meters, avoiding crowded 
places during a pandemic, washing hands using soap or hand sanitizer, taking a shower immediately and wash your hair after arriving home and wash all used clothes outside the home as well as get enough rest, be diligent in exercising and consume nutritious food to increase immunity. The results of this study are in line with research conducted by Honarvar, B., Lankarani, KB, Kharmandar, A. et al (2020) showing data that the majority of respondents have a positive attitude towards preventing Covid-19, namely $68.6 \%$, where preventive measures Covid-19 has been implemented by the community according to existing rules [10]. Attitude influences thinking to determine action, therefore attitude is important, but even though attitude is not always followed by behavior or action [11]

\subsection{The effect of health promotion on family knowledge and atti- tudes}

Based on research results of the recapitulation of the paired t-test showed a t-count value of $-17,568$. If this value is compared to the t-table of -1.99 , then the $t$-count is greater than the $t$-table. Then the $p$-value of 0.000 is smaller than 0.05 , meaning that there is a significant difference in family attitudes between before and after health promotion. Based on tables 4.2 and 4.3 the average value of the previous attitude was 3.32 and after being given health promotion the value became higher, which was only 3.50. Thus health promotion has a significant effect on family attitudes in a better direction than before. The results of this study are in line with Puryanto, et al (2009) that the influence of health education on students' knowledge and attitudes about the dangers of cigarettes, bivariate analysis used using the T Paired t-Test test in this study knowledge $p$ value 0.000 and attitude $p$ value 0.000 or $p<0.05$ hereby proves there is an effect of health promotion on knowledge levels and attitudes. [12]. The health implications of families inrancamanyar cluster can trigger or motivate health promoters as health workers to play an important role in their health level. Health promotion is a way to promote health, which aims to provide information in order to change the behavior of individuals or communities towards healthy living behaviors. But after the emergence of Covid-19 which then caused a global pandemic, the strategy of providing education has shifted in terms of delivery and educational methods. Various methods were developed through platforms that allow education to still be delivered even through face-to-face online such as Zoom used during research. Changes in strategies and educational methods are due to the policy of handling Covid-19 in the prevention of transmissions in the community to maintain physical and social distance andself-quarantine at home (Kemenkes RI and Task Force Covid-19, 2020). This condition does not allow health education to be applied 
as before Covid-19 occurred. Comorbid sufferers are not encouraged to leave the house let alone to health services that are still not said to be safe for the elderly if not in an emergency despite the high level of hand washing compliance in health workers during pandemics [13]. Since positive cases of Covid-19 have increased, many health care places are restricting visits and outpatient services. So comorbid sufferers are also unable to monitor the development of the disease regularly (Younie S, Et al. 2020). Efforts to improve health can not be separated from the role of education to provide a picture of health, the impact of a health disorder and preventive ways to improve health. People with chronic diseases have experience of complaints, symptoms and habits that affect the sufferer and triggers to change lifestyle, behavior and environment that can be at risk ofaffecting aperson's quality of life [2]. This research shows the role and supportof the family, during education interaksi by educators can take place well even though done virtually because the family prepares the media and communication tools needed during online education. This does not diminish the essence of education provided by researchers. In this study, the maturity factor of age, mindset based on gender, history of disease suffered and insight into knowledge obtained through education and sources of information obtained from electronic and digital media about Covid-19 added to the easier of education in improving about Covid-19 prevention. Education can encourage the improvement of respondents' health in preventing the spread of the virus among comorbid sufferers although education is very different from health promotion itself. Educational activities them selves are more focused on providing knowledge through witnessing with sufferers or patients. While health promotion focuses on ways of improving pro-health behavior [14]. Education is expected to change the perception of respondents to prevent the spread of the virus that has been formulated by the Ministry of Health and Task Force Covid-19 (2020) and the guide lines of the Health Protocol, where there are several points for control and prevention of spread including educational activities to wash hands using soapor handsanitizer, setting distance, surface and equipment disinfection periodically, and enforcement of discipline in the behavior of people who are at risk in transmission and contracting COVID-19 such as crowding, not using masks, smoking in public places and facilities and so on. Applied is necessary when this policy considering that digital media risks spreading inappropriate information about Covid-19 initsspread. In line with research that there isa relationship of health promotion through social media to Covid-19 prevention behavior in urban communities by 2020 [15]. The more effective the media in providing health promotion, the more individual behavior increases in preventing Covid-19. Empirical studies show that health education can increase knowledge and change unfavorable attitudes and 
behavior, effectively reducing cases of infectious diseases [16]. In accordance with research conducted in Nigeria, where the high level of knowledge and attitudes of correctional officers towards covid 19 reflects the efforts made by Nigerian correctional services institutions and the government to raise awareness of the general public about covid 19, and serve as a guide for awareness programs among correctional officers to be able to controlling the covid 19 epidemic [17] Knowledge and behavior proves that public literacy and attitudes related to disease play an important role in shaping community practice and control from the spread of the COVID-19 outbreak. [18].

\section{Conclusion}

Before being given health promotion in the prevention of the covid 19 pandemic, the level of family knowledge is the majority in the category of good and quite good. Meanwhile, after being given health promotion in the prevention of the covid 19 pandemic, the level of knowledge that has been good is even better even though there are still some who have enough knowledge. Family attitudes before being given health promotion the majority are in the category of very good and good with an average of 3.32 and after being given health promotion in the prevention of pandemic covid 19 family attitudes are still in the category of very good and good with an average of 3.50. Health promotion has a significant influence on family knowledge in the prevention of the covid 19 pandemic. Health promotion has a significant influence on family attitudes in the prevention of the covid 19 pandemic.

\section{Funding}

Immanuel School of Health Sciences Bandung supported this work.

\section{Acknowledgement}

The authors would like to thank their colleagues for their contribution and support to the research. They are also thankful to all the reviewers who gave their valuable inputs to the manuscript and helped in completing the paper.

\section{Conflict of Interest}

The authors have no conflict of interest to declare. 


\section{References}

[1] Ding J, Fu H, Liu Y, et al. Prevention and control measures in radiology department for COVID-19. European radiology. 2020;30(7):3603-8.

[2] Utama PJE. Edukasi penerapan protokol kesehatan sebagai upaya pencegahan penyebaran Covid-19 pada penderita komorbid. J IIm Kesehat Media Husada. 2021;10(1):34-41.

[3] Chen X, Ran L, Liu Q, Hu Q, Du X, Tan X. Hand hygiene, mask-wearing behaviors and its associated factors during the COVID-19 epidemic: A cross-sectional study among primary school students in Wuhan, China. International journal of environmental research and public health. 2020;17(8).

[4] Wowiling M, Rompas S, Karundeng M. Hubungan pengetahuan dan sikap keluarga dengan pencegahan demam berdarah dengue ( $\mathrm{Dbd}$ ) di kelurahan mogolaing. Jurnal Keperawatan UNSRAT. 2014;2(2):109281.

[5] Lin Y, Hu Z, Alias H, Wong LP. Knowledge, attitudes, impact, and anxiety regarding COVID-19 infection among the public in China. Frontiers in Public Health. 2020;8,236

[6] Willim HA, Ketaren I, Supit Al. Dampak coronavirus disease 2019 terhadap Sistem Kardiovaskular. e-CliniC. 2020;8(2):237-45.

[7] Younie S, Mitchell C, Bisson MJ, Crosby S, Kukona A, Laird K. Improving young children's handwashing behaviour and understanding of germs: The impact of $A$ Germ's Journey educational resources in schools and public spaces. PLoS One. 2020;15(11):1-19.

[8] Hanifah L, Sulistyorini E. Hubungan antara umur dengan pengetahuan wanita usia subur tentang pap smear. Avicenna: Journal of Health Research. 2019;2(1):113-20.

[9] Carter GT. Natural products and Pharma 2011: Strategic changes spur new opportunities. Natural product reports. 2011;28(11):1783-9.

[10] Honarvar B, Lankarani KB, Kharmandar A, et al. Knowledge, attitudes, risk perceptions, and practices of adults toward COVID-19: A population and field-based study from Iran. International journal of public health. 2020;65(6):731-9.

[11] Suprayitno E, Rahmawati S, Ragayasa A, Pratama MY. Pengetahuan dan sikap masyarakat dalam pencegahan COVID-19. Journal Of Health Science (Jurnal IImu Kesehatan. 2020;5(1):68-73.

[12] Nursaid I, Hartini S, Astuti R. Pengaruh pendidikan kesehatan bahaya merokok terhadap perubahan sikap anak tentang merokok Di SDIT al-firdaus gubug. Karya IImiah. 2016;18. 
[13] Moore, J. T., Ricaldi, J. N., Rose, C. E., Fuld, J., Parise, M., Kang, G. J., ... \& Honein, M. A. Disparities in incidence of COVID-19 among underrepresented racial/ethnic groups in counties identified as hotspots during June 5-18, 2020 - 22 States, February-June 2020. Morbidity and Mortality Weekly Report. 2020;69(33):1122-6.

[14] Whitehead D. Health promotion in nursing: A Derridean discourse analysis. Health promotion international. 2011;26(1):117-27.

[15] Mulyanti B, Purnama W, Pawinanto RE. Distance learning in vocational high schools during the Covid-19 pandemic in West Java province, Indonesia. Indonesian Journal of Science and Technology. 2020;5(2):271-82.

[16] Verelst F, Willem L, Beutels P. Behavioural change models for infectious disease transmission: A systematic review (2010-2015). Journal of The Royal Society Interface. 2016;13(125).

[17] Okoro J, Ekeroku A, Nweze B. Attitude and preventive practices towards COVID-19 disease and the impact of awareness training on knowledge of the disease among correctional officers. Emerald Open; 2020.

[18] Sørensen K, den Broucke S, Fullam J, et al. Health literacy and public health: A systematic review and integration of definitions and models. BMC Public Health. 2012;12(1):1-13. 